\title{
Sciendo
}

DOI: $10.2478 /$ jec-2019-0023

\section{THE ROLE OF SMALL BUSINESS IN THE ECONOMY AND METHODS OF ITS GOVERNMENT SUPPORT USING THE EXAMPLE OF THE REPUBLIC OF LATVIA}

\author{
Ludmila Verovska', Renate Zujeva ${ }^{2}$ \\ Ludmila Verovska, Baltic International Academy, Riga, Latvia, mila.v@inbox.lv. \\ Renate Zujeva, Baltic International Academy, Riga, Latvia, zujeva.renate@gmail.com
}

\begin{abstract}
Research purpose. The purpose of this study was to determine the role of small and medium enterprises in the economy, as well as to study and evaluate the effectiveness of government support methods for small business entities (SMEs) using the example of the Republic of Latvia. The subject of the research was the system of state regulation and promotion of SME development. The object of the research was the sphere of small business in the Latvian economy, including SMEs, infrastructure support and development of small business.
\end{abstract}

Design/Methodology/Approach. The study used basic methods of scientific knowledge of economics: an interdisciplinary approach combining methods of systems and comparative analysis, an integrated approach, induction, deduction, analysis, synthesis, methods of organization theory and management, logical analysis, strategic management and also economic analysis of small businesses.

Findings. The research resulted in a system of state regulation and promotion of SME development in Latvia developed by the author, based on an assessment of the impact of measures provided to support SMEs, taking into account the importance of the role of small business in the economy of the Republic of Latvia.

Originality/Value/Practical implications. The practical significance of the work is that the study completes a number of conclusions and practical recommendations in the field of organizational measures for effective support and multilateral development of the SME sector in the economy, recognition of the role of small business as the basis of the economic stability of the Republic of Latvia and the effectiveness of its support as the main state economic policy goal.

Keywords: government support for small businesses; Latvian economy; small business; SME.

JEL codes: E60; G28; H71; R11.

\section{Introduction}

Today, according to statistics, small and medium businesses (hereinafter referred to as SMEs) are the basis of the socio-economic well-being of the countries of the European Union. The rapid growth of the small business sector in all industries and agriculture in Europe began in the mid-1970s and continues to this day. Small business is characterized by flexibility, agility, the ability to quickly respond to the slightest changes in the economic environment and market requirements. This contributes to expanding the range and improving the quality of goods and services and introducing innovations and new technologies and also plays a significant role in creating new jobs and, as a result, reducing unemployment.

Understanding the important role of small business in the EU countries and taking into account the priorities of the Europe 2020 long-term development strategy, the absolute majority of developed countries provide feasible support in creating and further developing small business sector enterprises.

Analysing the current state of the Latvian economy, it seems that the state policy of the Republic of Latvia regarding the support of small and medium-sized businesses is insufficient. This hypothesis formed the basis of the study. 
The purpose of this article is to explore the features of state policy aimed at supporting and developing small business in the European Union and the Republic of Latvia and to assess the attitude of business towards its implementation.

\section{Literature Review}

As mentioned above, SMEs in the modern world are key elements of a stable and strong market economy, without which it is impossible to imagine the effective development of any state. In the context of a progressive and protracted economic crisis, one of the most promising areas for the all-round development of the European Union, creating new jobs and, as a result, reducing unemployment and social tension and filling the consumer market with affordable and competitive, as well as innovative products and services, is the comprehensive support and promotion of the development of small and medium-sized businesses.

However, to begin the study, it is necessary to determine the terminology used: the fulfilment of which criteria allows the enterprise to be classified as a small business?

So, in the European Union, of which the Republic of Latvia has been a member since 2004, the issue of classifying enterprises as small and medium-sized businesses is almost solved at the legislative level. The definition of SMEs is specified in EU Recommendation 2003/361 (European Commission, 2003). According to the context of this document, an enterprise is considered to be any unit, regardless of its organizational and legal form, engaged in economic activity. This includes, in particular, individual entrepreneurs (self-employed persons) and family enterprises that are engaged in craft activities or other activities, as well as partnerships or associations that are regularly engaged in economic activities. To simplify the understanding and determination of the status of an economically active business entity, on 6 August 2008, the European Commission announced Regula No. 800/2008 (European Commission, 2008), in which the main definitions and criteria were given. The main factors determining whether an enterprise belongs to SMEs, hereinafter referred to as small enterprises, are: number of staff and net turnover, or the total book value.

The basis for regulating the activities of small enterprises in the European Union is the initiative of the European Commission, which was adopted in June 2008 and was called 'Think first about the small first' - 'Small Business Act for Europe' (SEC,2008), which was approved by the Council in December 2008. The Small Business Act (SBA) provides a comprehensive policy framework for SMEs, promotes entrepreneurship and enshrines the 'Think Small First' principle in law and policy to improve the competitiveness of SMEs. The SBA establishes 10 principles and sets out policy and legislative measures to promote the development of SMEs for their growth and job creation, both at EU level and at the level of Member States. These principles, set out in detail, are necessary to provide added value at EU level, create equal conditions for SMEs and improve the legal and administrative environment throughout the EU.

The long-term goals of small business development and support are described in the European Development Strategy - Europe2020 (European Commission, 2010), and the main provisions of the SBA are also reflected in the long-term development strategies of the European Union member countries, for example, in the state program 'Latvia 2020' (VARAM, 2013). The European Commission monitors the implementation of the Law 'On Small Business' and annually publishes the results of this study (European Commission, 2016, 2019). Such a great attention to SMEs at the EU leadership level is not paid accidentally, because at the moment, it is the value of the SME sector in the EU countries that is determined by its share in the total number of enterprises, total turnover and total number of employed people. Table 1 provides summarized data on the number and size of enterprises in EU countries, the number of employees and the total value added, as well as the percentage ratio of these indicators as of the beginning of 2019 . 
Table 1. SME key performance indicators in the EU as on 1 January 2019. (Source: European Commission SME Performance Review 2019)

\begin{tabular}{|c|r|r|r|r|r|r|}
\hline \multirow{2}{*}{ Class size } & \multicolumn{2}{|c|}{ Number of enterprises } & \multicolumn{2}{c|}{$\begin{array}{c}\text { Number of persons } \\
\text { employed }\end{array}$} & \multicolumn{2}{c|}{ Value added } \\
\hline & \multicolumn{1}{|c|}{ Number } & \multicolumn{1}{|c|}{ Share } & \multicolumn{1}{c|}{ Number } & \multicolumn{1}{c|}{ Share } & Billion EUR & \multicolumn{1}{|c|}{ Share } \\
\hline Micro & 22830945 & $93.1 \%$ & 41980528 & $29.4 \%$ & 1513 & $20.7 \%$ \\
\hline Small & 1420693 & $5.8 \%$ & 28582254 & $20.0 \%$ & 1302 & $17.8 \%$ \\
\hline Medium-sized & 231857 & $0.9 \%$ & 24201840 & $17.0 \%$ & 1341 & $18.3 \%$ \\
\hline SMEs & $\mathbf{2 4 4 8 3 4 9 5}$ & $\mathbf{9 9 . 8 \%}$ & $\mathbf{9 4 7 6 4 6 2 2}$ & $\mathbf{6 6 . 4 \%}$ & $\mathbf{4 1 5 6}$ & $\mathbf{5 6 . 8 \%}$ \\
\hline Large & 46547 & $0.2 \%$ & 47933208 & $33.6 \%$ & 3166 & $43.2 \%$ \\
\hline Total & $\mathbf{2 4 5 3 0 ~ 0 4 2}$ & $\mathbf{1 0 0 . 0} \%$ & $\mathbf{1 4 2 ~ 6 9 7 ~ 8 3 0}$ & $\mathbf{1 0 0 . 0 \%}$ & $\mathbf{7 3 2 2}$ & $\mathbf{1 0 0 . 0 \%}$ \\
\hline
\end{tabular}

As can be seen from Table 1, small and medium-sized enterprises are indeed the basis of the economic and social well-being of the European Union, since, constituting more than $99.5 \%$ of the total number of enterprises in the EU, more than $66 \%$ of the working staff are employers and bring in the cumulative budget of about $60 \%$ of value added. That is why the effective support and promotion of development at both the pan-European and regional levels is given special attention.

The main purpose of building an enterprise support system in the EU countries is to create a certain balance between the interests of the state and business representatives, and the following areas of this regulation are provided for 1) formation of a single domestic market; 2) internationalization of business structures; 3) elimination or significant reduction of administrative barriers, and 4) unification of the legal framework for small business enterprises.

The national policy in the countries of the European Union is aimed at creating and enabling environment for business development. State assistance to the development of small and medium-sized businesses includes the provision of most favoured nation treatment and creation by state institutions of legal and economic conditions for its successful development and functioning, including the provision of material and financial resources on preferential terms. State regulation of SME is based on the application of special legislation, a system of targeted programs of financial, technological, informational and personnel support. The system of state support and regulation of the SME sector began to take shape in Europe since the early 1970s: actions were taken to reduce administrative barriers, measures were taken to simplify and harmonize the value-added tax, adjustments were made to the terms of financing and lending, increased transparency of payment systems and availability of banking services. In general, the system of state support for small businesses can be represented in the form of the diagram shown in Figure 1.

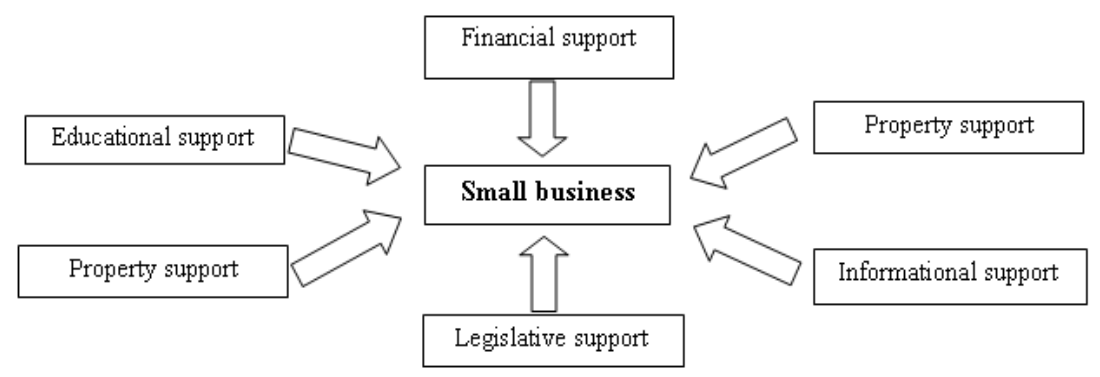

Fig.1. Methods of government support for SME (Source: authors' compilation) 
The implementation of a wide range of forms and methods of state support can have a significant impact on the development and functioning of both an emerging and an active enterprise. Financial support at this stage is government subsidies for setting up a business, concessional lending from the state budget, state guarantees for the creation and development of an enterprise, financing investment and innovation projects, program business angels and so on. Property support from the state may look like the creation of business incubators, technology parks, the transfer of movable and immovable property for temporary or permanent use, as well as in the ownership of an entrepreneur, preferential leasing conditions. Information support is expressed in the organization of the information distribution system, the creation of a centralized network for the exchange of business information, information seminars and stands, and the organization of industry or regional exhibitions. The most important forms of support are educational (aimed at creating conditions for enhancing the professional knowledge and skills of an entrepreneur, developing comprehensive educational programs, as well as training seminars and lectures) and a consulting form of support aimed at creating organizations that provide consulting services in organization, development assistance and peculiarities of doing business, as well as compensation to businessmen for the costs of consulting services. But, of course, one of the most significant forms of support should be considered legislative, which is primarily aimed at simplifying and reducing the tax and administrative burden, such as reducing the forms and types of reporting, the number of procedures for registering a company and introducing preferential tax regimes.

As mentioned above, the main documents for EU member states regarding small enterprises are the regulations and guidelines of the European Commission. However, each country of the European Union has its own internal regulatory documents. In Latvia, the activities of small enterprises are not regulated by separate regulatory acts, with the exception of a separate Law of the Republic of Latvia of 9 August 2010, 'On microenterprise taxpayers' (LR Saeima , 2010), and Cabinet of Ministers Regulations No. 776 of 16 December 2014, 'On the procedure for a commercial company to declare its compliance with the status of a small and medium-sized enterprise'. The last regulatory act is related to the status declaration in the situation of an enterprise receiving state support.

Of course, taking into account the importance of this sector of the economy, scientists from all over the world are engaged in the study of small businesses. Some are analysing the possibility and effectiveness of using additional financing in the form of bank loans and grants, as well as government subsidies and loans (Kodongo 2015, Bhusal 2015, Abdulsaleh, Abdulaziz M. A, 2016, Wang, 2016, Moritz, 2015). Others turn their attention to the problems of managing small enterprises and the possibilities of introducing control and management systems (Tsõgankova 2014). Still others study the role of the human factor and the characteristics of personnel management to increase the efficiency of entrepreneurship development in the small business sector (Abduli 2013, Soinsaari 2014, Ozolina-Ozola 2011, Ali Husien 2012). In 2014, a very interesting study was conducted by young scientists from the Polish University of Technology in Lodz (Matejun 2014), comprehensively examining the main problems that small enterprises in this country face: starting from the possibilities of obtaining financing, using various funds, business incubators and introducing new technologies, to problems with the search and management of personnel in small family enterprises.

According to the data of the annual report of the European Commission, small and medium-sized businesses also form the basis of the social and economic welfare of the Republic of Latvia. The main indicators by the number of enterprises, employed persons and total value added as of 1 January 2019 are shown in Table 2.

Table 2. SME key performance indicators in Latvia as of 1 January 2019. (Source: European Commission SME Performance Review, 2019)

\begin{tabular}{|c|r|r|r|r|r|r|}
\hline Class size & \multicolumn{2}{|c|}{ Number of enterprises } & \multicolumn{2}{c|}{$\begin{array}{c}\text { Number of persons } \\
\text { employed }\end{array}$} & \multicolumn{2}{c|}{ Value added } \\
\hline & Number & Share & Number & Share & Billion EUR & Share \\
\hline Micro & 104795 & $92.1 \%$ & 208970 & $33.5 \%$ & 2.5 & $20.9 \%$ \\
\hline
\end{tabular}




\begin{tabular}{|c|r|r|r|r|r|r|}
\hline Small & 7344 & $6.5 \%$ & 146547 & $23.4 \%$ & 2.8 & $23.0 \%$ \\
\hline Medium-sized & 1421 & $1.2 \%$ & 138276 & $22.1 \%$ & 3.2 & $26.1 \%$ \\
\hline SME`s & $\mathbf{1 1 3 5 6 0}$ & $\mathbf{9 9 . 8 \%}$ & $\mathbf{4 9 3 7 9 3}$ & $\mathbf{7 9 . 0} \%$ & $\mathbf{8 . 5}$ & $\mathbf{7 0 . 0 \%}$ \\
\hline Large & 195 & $0.2 \%$ & 131173 & $21.0 \%$ & 3.6 & $30.0 \%$ \\
\hline TOTAL & $\mathbf{1 1 3 7 5 5}$ & $\mathbf{1 0 0 . 0 \%}$ & $\mathbf{6 2 4 9 6 6}$ & $\mathbf{1 0 0 . 0} \%$ & $\mathbf{1 2 . 1}$ & $\mathbf{1 0 0 . 0 \%}$ \\
\hline
\end{tabular}

Comparing the figures of Table 2 with the general data for the European Union - the data in the first section - it can be stated that the share of micro enterprises with up to 10 employees in the European Union is slightly higher than in Latvia $-93.1 \%$ and $92.1 \%$, respectively; however, the share of small and medium-sized enterprises in Latvia is somewhat higher than in the EU as a whole, although the overall percentage is the same $-99.8 \%$. However, analysing the number of people employed in small (SME) enterprises, the share in Latvia is significantly higher than in the European Union as a whole $79.0 \%$ versus $66.4 \%$, respectively. The situation is similar with value added: in Latvia, the share brought by small enterprises, according to the EC study, is $70.0 \%$, while in the EU as a whole, this figure is just over half $-56.8 \%$. Taking into account the data of the above analysis, we can state the following: the small business sector is particularly important from both the economic and the social side, because it makes a significant contribution to the state budget, provides jobs, thus reducing unemployment and social tension. That is why comprehensive support and promotion of development should be the basis of the economic development program of the Latvian state.

Unfortunately, it is the state influence in the field of legislation that is the most significant factor for the development and existence of a small business in Latvia (Central Statistical Bureau of Latvia, 2019). State-led tax changes and reforms do not always lead to the expected result. For example, in mid-2017, several legal acts related to significant changes in the tax legislation of the Republic of Latvia were again approved, which in the future should have led to an increase in tax revenues to the state budget in order to compensate for the growing budget expenditures. These changes were called 'Tax Reform 2018'.

Of course, the final results of tax reform can be seen only after 2 years, as presented by the government: it was precisely during 2 years that it was planned to significantly increase tax revenues, remove part of the business from the shadows and improve the social environment by increasing the minimum wage, introducing income tax differentiation from the population. However, at the moment it can already be stated that the tax reform did not stop the outflow of the population from the country, because due to the increase in taxes such as the excise tax on fuel, prices for industrial goods and food increased and the cost of transport and other services increased, which did not simply offset the increase in net wages, but also led to a reduction in incomes. 'Tax reform 2018' (Zujeva, 2016) also had a negative impact on the development of small and medium-sized businesses. Table 3 provides information on the registration and liquidation of enterprises in Latvia for the period from 2008 to 1 January 2019.

Table 3. The number of established and liquidated enterprises in the period from 2008 to 2019 (Source: author's compilation, Lursoft, 2019)

\begin{tabular}{|c|c|c|c|}
\hline Year & Registered & Liquidated & Balance \\
\hline $\mathbf{2 0 0 8}$ & 11347 & -4765 & 6582 \\
\hline $\mathbf{2 0 0 9}$ & 9228 & -5715 & 3513 \\
\hline $\mathbf{2 0 1 0}$ & 13422 & -8833 & 4589 \\
\hline $\mathbf{2 0 1 1}$ & 18044 & -3921 & 14123 \\
\hline $\mathbf{2 0 1 2}$ & 16891 & -4306 & 12585 \\
\hline $\mathbf{2 0 1 3}$ & 16365 & -4152 & 12213 \\
\hline $\mathbf{2 0 1 4}$ & 14965 & -6402 & 8563 \\
\hline
\end{tabular}




\begin{tabular}{|c|c|c|c|}
\hline $\mathbf{2 0 1 5}$ & 13485 & -10066 & 3419 \\
\hline $\mathbf{2 0 1 6}$ & 11206 & -12227 & $\mathbf{- 1 ~ 0 2 1}$ \\
\hline $\mathbf{2 0 1 7}$ & 10210 & -16480 & $\mathbf{- 6 ~ 2 7 0}$ \\
\hline $\mathbf{2 0 1 8}$ & 10660 & -20745 & $\mathbf{- 1 0 ~ 0 8 5}$ \\
\hline $\mathbf{2 0 1 9 *}$ & 8538 & -21157 & $\mathbf{- 1 2 ~ 6 1 9}$ \\
\hline
\end{tabular}

Table 3 was compiled by the authors on the basis of data from a study by the company Lursoft, and it vividly illustrates the attitude of entrepreneurs to the possibilities of doing business in our country. If in the post-crisis period, starting from 2008, the number of registered enterprises grew and significantly exceeded the number of liquidated enterprises, reaching the largest peak in 2010-2011, after the introduction of a preferential regime for micro-tax payers, significant changes in tax legislation in 2016, a constant increase in tax rates, introduction of additional restrictions and a multiple increase in administrative burden, business representatives began to liquidate their enterprises en masse. In February 2019, Lursoft reiterated in its blog (Lursoft, 2019) that the enterprise register eliminated 6647 merchants in just one day on 14 January, and during the day of 13 February, 3408 enterprises were also liquidated. Considering that from the beginning of the year and until 1 October 2019, according to the Register of Enterprises, only 8538 enterprises were created, the statistics of this year again show a negative picture - entrepreneurs see no reason to create their own business in the Republic of Latvia.

Unfortunately, such extensive studies of the small business sector in the Baltic countries were not conducted; however, scientists still considered the regional characteristics of entrepreneurship in Latvia, Lithuania and Estonia (Zujeva 2016, 2018, Dickinson 2014, Vaitkevicius, 2014, Kochetkov \& Sventitskaya 2016). Young Latvian scientists turned their attention to increasing the competitiveness of small enterprises (Volvenkins 2012, Drinke \& Bruksle 2018, Vanags 2019). However, on the topic of assessing the state support system for small businesses and the effectiveness of its application in the Latvian Republic, no studies have been conducted before.

\section{Methodology}

As already mentioned in the first section of this article, to stimulate the creation and development of small businesses, the government can provide the following types of support: financial, property, informational, educational, consulting and legislative; the description of each of them has also been given earlier. However, it is interesting to analyse the expectations of business representatives regarding the possible support from the state. In other words, which types of support are the most important and essential for future and current entrepreneurs?

Data analysed in the current study was obtained from survey participants organized and developed by the study authors. In March 2019, 367 respondents, active Facebook users who are not indifferent to the economic situation in the Republic of Latvia, participated in the survey.

To be representative, the sample size should be approximately 1,188 participants, taking into account population statistics for 2017 in the age group of 18-56 years (Central Statistical Bureau, 2017). The authors had data from only 104 participants who provided high-quality answers to all questions.

Of the participants, $71 \%$ women, and $29 \%$ were men; $75 \%$ had higher education; $48 \%$ of the total number of participants represented the city of Riga (the capital of Latvia).

The questionnaire was developed by the authors of the study and consisted of 13 questions suggesting different answer options, such as choosing a specific answer from the proposed ones, as well as a 6point priority system for evaluating various indicators.

All questions were grouped into three content blocks:

1. Data on survey participants, such as gender, age, place of residence, level of education, type of employment of the respondent. 
2. A group of questions regarding the purpose of the study: respondents were asked to place the proposed elements of the state support system for small businesses, such as financial, legislative, business, information, educational and consulting, in order of importance in the creation, development and active work of small businesses in the Republic of Latvia - from the most important to the most insignificant, based on a 6-point rating system, according to the number of elements presented, respectively; the higher the position of the element, the higher its value in the system and the greater the coefficient. It was also proposed to determine what the position of the state in relation to SMEs was, assessing the level of state support from significant to complete lack thereof.

3. The third block was devoted to the assessment by respondents of their own knowledge and skills needed to create, register and conduct their own small businesses, as well as the ease of doing business in the Republic of Latvia and the thoughts of respondents regarding the topic of the study.

Below are summarized the results of the study received from respondents in Part B, which correspond to the immediate purpose of this article. Part $\mathrm{C}$ results will be presented in the next article.

\section{Results}

An analysis of the data of the study shows (Fig.2.) that respondents consider financial assistance in the form of subsidies, additional financing, soft loans, investment financing and innovative projects to be the most important at all stages of enterprise development from registration to activities. Further, with a small margin and legislative support follows, respondents especially noted difficulties in perceiving the norms of the Latvian legislation, complex and incomprehensible forms of reporting and constant changes in regulatory acts. The property support form is also important, in which entrepreneurs expect help in the form of preferential leasing conditions, the possibility of simplified access to business incubators and industrial parks. An informational, educational and consulting form of support is also noted as desirable; however, according to respondents, they are significantly behind in importance from the first three described above.

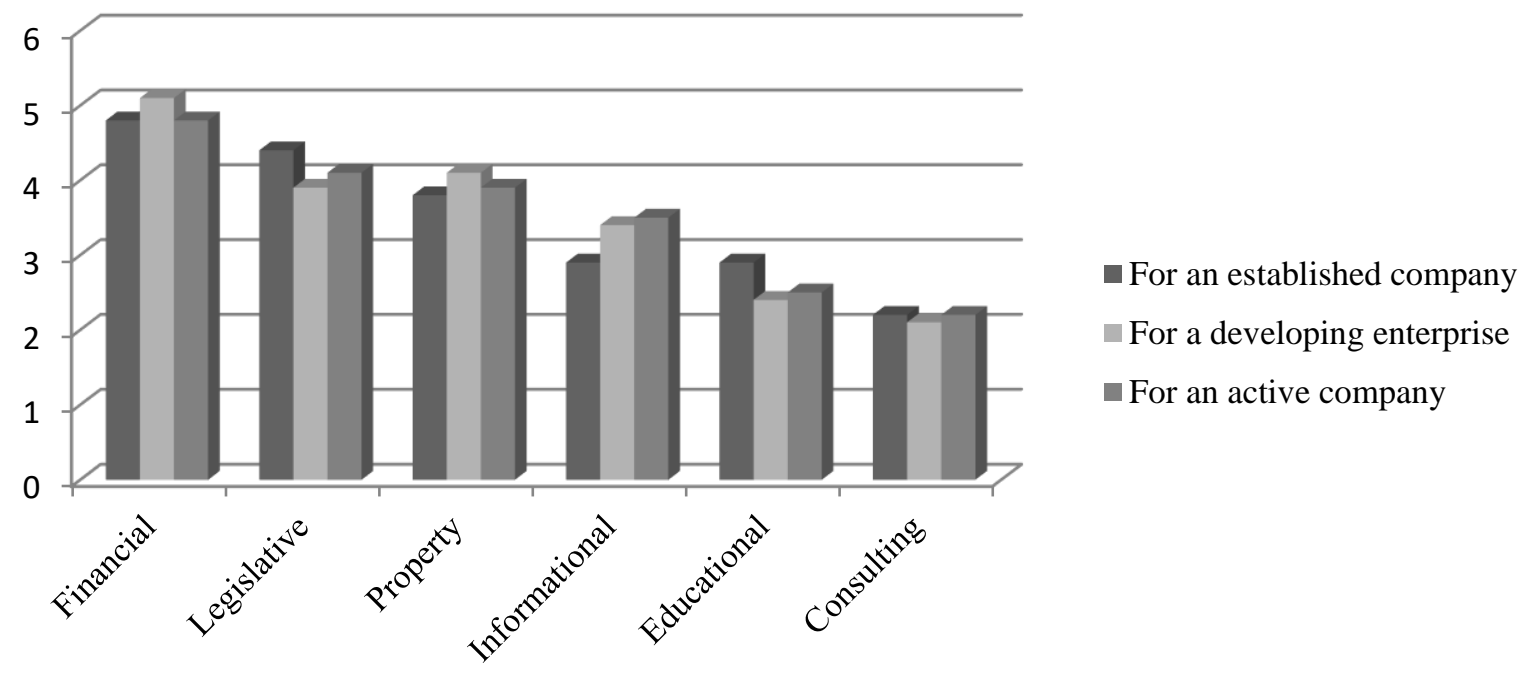

Fig.2. Priorities of types of state support for the enterprise at different stages of its existence (Source: author's research results)

To the research question regarding the level of state support to small and medium-sized enterprises, the following answers were received (illustrated in Fig. 3): the majority of respondents are sure that the state is not doing enough to develop small business in Latvia, such was $51 \%$ of all respondents. And $45 \%$ of respondents are convinced that the state does nothing at all for the successful 
development of small and medium-sized businesses in Latvia, whereas only $4 \%$ said that the state provides all possible assistance in supporting and developing this sphere of entrepreneurial activity.

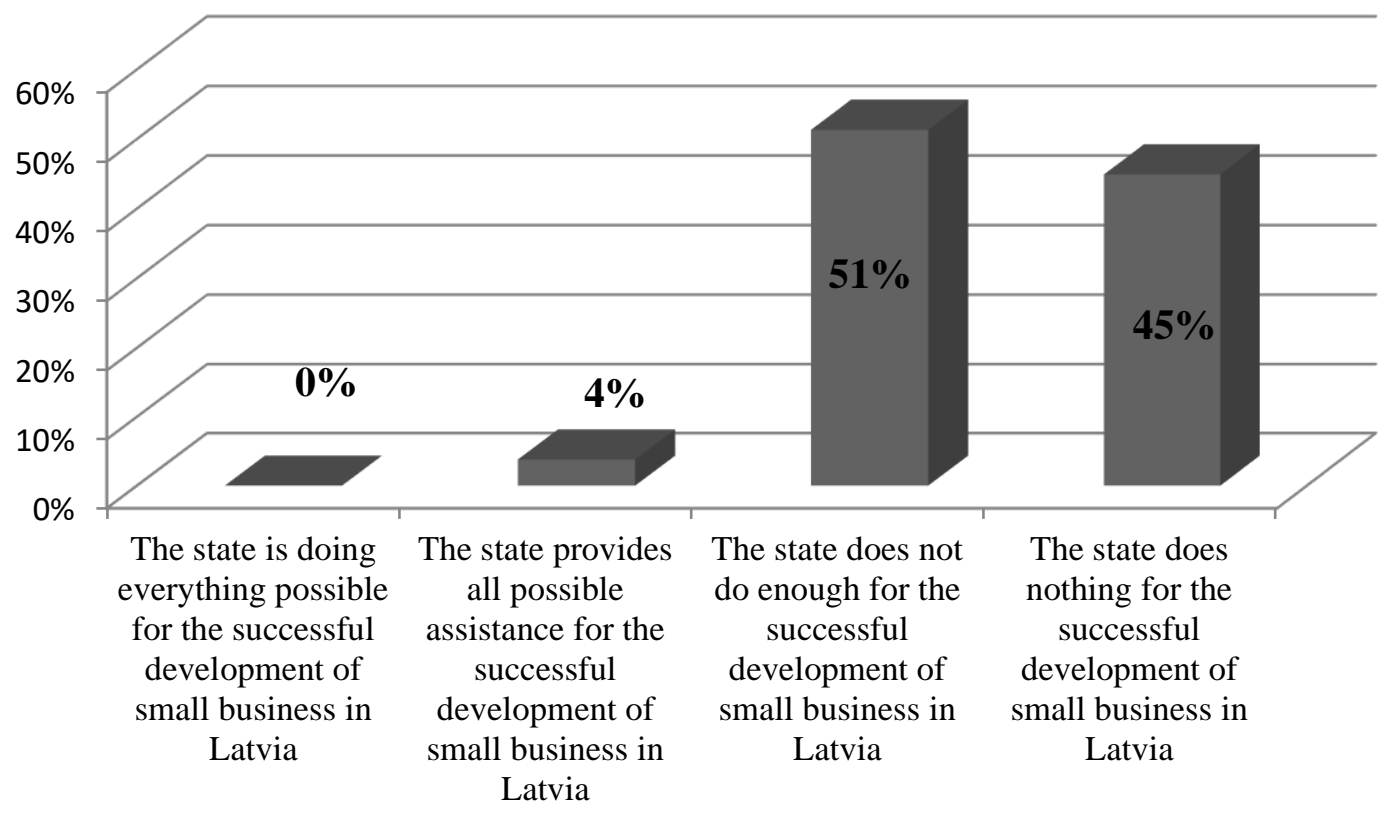

Fig.3. Priorities of types of state support for the enterprise at different stages of its existence (Source: author's research results)

During the survey, a public opinion poll was also conducted on whether it was easy to do business in Latvia. According to the responses received, $88.5 \%$ of respondents noted that it is very difficult to engage in entrepreneurial activities in Latvia due to the large number of restrictions, too high requirements of the legislation and complex reporting. Many of the respondents complained about the difficulties in the perception of regulations and incomprehensible and biased tax system, due to which the company incurs a large number of unplanned costs, which in turn push away potential investors. Among those interviewed were those who were forced to close their business precisely because of the aforementioned difficulties. Research in this area will be continued.

\section{Conclusions}

The study conducted in this article shows that small business can rightfully be called the basis of the economic and social well-being of the European Union as a whole and the Republic of Latvia in particular. Enterprises in this sector of the economy create new jobs and make a significant contribution to budget revenues and to the growth of the gross national product of the EU countries.

Recognizing the role and importance of small enterprises, the European Union has created a number of documents regulating the support of these enterprises and has developed a comprehensive assistance system to create and promote the development of this sector of the economy - financial, informational, educational and so on.

Based on the research and questionnaire data, a number of problems were identified in the state support system for small businesses, which significantly limited the activities of enterprises in this sector of the Latvian economy. This, in turn, runs counter to the general policy of the European Commission regarding the policy of active support and stimulation of the development of small business in the European Union. Analysing the research of scientists in the field of small business development in other European countries, for example, the extensive study of Polish scientists mentioned above, we can conclude that, in general, the situation in many countries is very close: enterprises encounter difficulties in obtaining financing, selecting and HR management, regional features of the law. And sometimes the 
measures taken by the government of a particular state do not always meet the interests of small and medium-sized businesses in a particular region or even the country's population. As a result, significant imbalances arise, clearly illustrated by the example of the Republic of Latvia in the earlier section of this article.

Therefore, when addressing serious issues such as a significant change in tax legislation, government agencies should conduct a preliminary comprehensive assessment of the impact of the proposed changes, taking into account the opinions of representatives of all types of businesses and the recommendations of international organizations. The implementation of tax reform and other important changes in the legislation in the field of entrepreneurship should correspond to the priorities of the development of the country and small business, which today is a priority for the development of the EU economy, as has been repeatedly emphasized. It is small business that plays a significant role both in GDP growth in all countries of the European Union and in employment. And the legislative system is a key tool for the harmonious regulation of this environment.

\section{References}

Abdulsaleh, M. A, Worthington A. (2016). Bank Financing for Small and Medium-sized Enterprises (SMEs) in Libya, [Accessed 28.03.2019]. Available from Internet: https://www.semanticscholar.org/paper/Small-andMedium-Sized-Enterprises-Financing\%3A-A-of-AbdulsalehWorthington/f2d063d474408ebbf20eae1cb1b5e7905e7382d8

Bhusal R.(2015). SME Finance in Nepal: relevance of bootstrapping finance [Accessed 28.03.2019]. Available from Internet: https://www.researchgate.net/publication/281901241_SME_Finance_in_Nepal_relevance_of_bootstrapping_fina nce

Central Statistical Bureau of Latvia, (2019). Statistics for Latvia's SME [Accessed 30.03.2019]. Available from Internet:

https://data1.csb.gov.lv/pxweb/lv/uzn/uzn__uzndarb/SBG020.px/table/tableViewLayout1/?rxid=491bb1902600-453b-867d-5ac9b6a69264

Drinke Z., Bruksle I. (2018). Quality management system as tool for corporate development and competitiveness increase in small and medium companies [Accessed 28.03.2019]. Available from Internet: https://llufb.llu.lv/conference/economic_science_rural/2018/Latvia_ESRD_47_2018-65-72.pdf

European Commission, (2003). Commission Recommendation of 6 May 2003 concerning the definition of micro, small and medium-sized enterprises (Text with EEA relevance) (notified under document number C(2003) 1422) [Accessed 29.03.2019]. Available from Internet: https://eur-lex.europa.eu/legalcontent/EN/TXT/?uri=CELEX:32003H0361

European Commission, (2008). A "Small Business Act" for Europe \{SEC(2008) 2101\} \{SEC(2008) 2102\} "Think Small First", [Accessed 29.03.2019]. Available from Internet: https://eur-lex.europa.eu/legalcontent/EN/TXT/?uri=CELEX:52008DC0394

European Commission, (2008). Commission Regulation (EC) No 800/2008, [Accessed 29.03.2019]. Available from Internet: https://eur-lex.europa.eu/LexUriServ/LexUriServ.do?uri=OJ:L:2008:214:0003:0047:en:PDF

European Commission, (2008). Indicators to support the Europe 2020 strategy, [Accessed 28.03.2019]. Available from Internet: http://ec.europa.eu/eurostat/documents/3217494/7566774/KS-EZ-16-001-EN-N.pdf/ac04885ccfff-4f9c-9f30-c9337ba929aa

European Commission, (2008). User guide to the SME Definition, [Accessed 29.03.2019]. Available from Internet: http://ec.europa.eu/regional_policy/sources/conferences/state-aid/sme/smedefinitionguide_en.pdf

European Commission, (2010). Europe 2020 Strategy, [Accessed 28.03.2019]. Available from Internet: https://ec.europa.eu/info/business-economy-euro/economic-and-fiscal-policy-coordination/eu-economicgovernance-monitoring-prevention-correction/european-semester/framework/europe-2020-strategy_en

European Commission, (2019). SME Performance Review, SBA Fact sheets of Latvia and EU, Accessed 30.03.2019]. Available from Internet: https://ec.europa.eu/growth/smes/business-friendlyenvironment/performance-review_en, 
Kodongo O. (2015). The role of financial access in the success of small and medium enterprises in Swaziland [Accessed 30.03.2019]. Available from Internet: http://wiredspace.wits.ac.za/jspui/bitstream/10539/21039/1/Zethu\%20Mthethwa\%20Final\%20Paper\%20Aug\%2 02015.pdf

LR Ministru kabinets (2014). LR Ministru kabineta noteikumi Nr.776, Kārtība, kādā komercsabiedrības deklarē savu atbilstību mazās (sīkās) un vidējās komercsabiedrības statusam, [Accessed 29.03.2019]. Available from Internet: https://likumi.lv/ta/id/271191-kartiba-kada-komercsabiedribas-deklare-savu-atbilstibu-mazas-sikas-unvidejas-komercsabiedribas-statusam

LR Saeima.(2010). likums “Mikrouzņēmumu nodokḷa likums”, [Accessed 29.03.2019]. Available from Internet: https://likumi.lv/doc.php?id=215302

Lursoft. (2019). Liquidated enterprises. Statistic facts, Lursoft blog. [Accessed 29.03.2019]. Available from Internet: http://blog.lursoft.lv/tag/likvidetie-uznemumi/

Moritz A. (2015). Financing of Small and Medium-Sized Enterprises in Europe - Financing Patterns and 'Crowdfunding', [Accessed 28.03.2019]. Available from Internet: https://ubt.opus.hbz-nrw.de/opus45ubtr/frontdoor/deliver/index/docId/693/file/Dissertation_Alexandra_Moritz.pdf

Nguyen S.T. (2017). An Analysis of SMEs Funding, Bank Efficiency and Barriers to Lending: Three Essays, [Accessed 28.03.2019]. Available from Internet: https://eprints.soton.ac.uk/378767/1/Final\%2520PhD\%2520thesis\%2520-\%2520Son\%2520Nguyen.pdf

Ozoliņa-Ozola, I.(2011). Cilvēku resursu vadīšanas efektivitātes novērtēšanas problēmas. Ekonomika un uzṇēmējdarbiba. Nr.21, 2011, 67.-75.lpp. ISSN 1407-7337 [Accessed 28.03.2019]. Available from Internet: https://ortus.rtu.lv/science/lv/publications/12510

Soinsaari A. (2014). Creating human resource policy for an sme company. [Accessed 28.03.2019]. Available from Internet: https://www.theseus.fi/bitstream/handle/10024/83932/Soinsaari_Anssi.pdf?sequence=1\&isAllowed=y

VARAM (Vides aizsardzības un regionālās attīstības ministrija), (2013). Latvijas Nacionālais attīstības plāns 2014. - 2020.gadam, [Accessed 29.03.2019]. Available from Internet: http://www.varam.gov.lv/lat/pol/ppd/ ilgtsp_att/?doc $=13858$

Volvenkins S. (2012). Mazo un vidējo uzņēmumu konkurētspējīgu priekšrocību radīšana un virzīšana tirgū, izmantojot mārketinga instrumentus interneta vidē. [Accessed 28.03.2019]. Available from Internet: https://dspace.lu.lv/dspace/bitstream/handle/7/5117/22844-Sergejs_Volvenkins_2012.pdf?sequence=1

Wang J. (2016). SME financing in Zhejiang province, [Accessed 28.03.2019]. Available from Internet:http://etheses.dur.ac.uk/11675/1/SME_financing_in_Zhejiang_province_WANG_Jinhua.pdf?DDD2+

Zujeva,.R, (2016). ВIA, Влияние государственной политики в сфере налогообложения на развитие малого бизнеса Латвии, in V International Scientific Conference Transformational Processes in Law, Regional Economics and Economic (BSA Conference proceedings, 2016, 78-82)

Zujeva,R., (2018). BIA. Mazo un vidējo uzṇēmumu loma Baltijas valstu un Eiropas Savienības ekonomikā, in VII International Scientific Conference Transformational Processes in Law, Regional Economics and Economic (BSA Conference proceedings, 2018,114-119) 